\title{
Estimating Optimum Growth-Maximizing Public Debt Threshold for Nepal
}

\author{
Gopal Prasad Bhatta, PhD* \\ and Anu Mishra ${ }^{* *}$
}

\begin{abstract}
One of the common agenda of underdeveloped economies is to achieve a high and sustainable level of economic growth in the long run. Domestic and external borrowings are playing a crucial role in fulfilling the resource gap in the context of Nepal for a long period. A growing number of recent studies support the idea of a debt threshold level (turning point) above which debt starts reducing economic growth. This paper empirically investigates the relationship between economic growth and several other factors (investment, trade openness, population growth, domestic savings, and government debt) in the context of Nepal. The debt-growth relationship has been estimated by regression analysis and further explored the non-linear relationship between public debt and economic growth using time series annual data for the period of 1976-2019. The ARDL bound technique has been applied to estimate the short-run and the long run impact of debt on economic growth. Moreover, a quadratic bivariate model based on ARDL coefficients has been estimated to identify the growth maximizing level of debt. The estimated parameters confirm the optimum public debt to GDP ratio in the context of Nepal is 33 per cent. The policy implication of this finding for the Government of Nepal (GoN) is to ensure public debt management in line with the growth maximizing debt threshold. Further, a high level of trade deficits and government effectiveness in public sector management squeezes the fiscal space in utilizing adequate public debt in Nepal.
\end{abstract}

Key Words: Public debt, economic growth, Laffer-curve, developing economies, growth maximizing debt threshold

\section{JEL Classification: E01, E44, F62, F63, N15}

* Dr. Bhatta, is a former Executive Director of Nepal Rastra Bank (Central Bank of Nepal), banking expert in the high level "Sick Industry Rehabilitation Committee" formed by GoN, public debt expert and consultant, and associated with many colleges of Tribhuvan University (Nepal), Pokhara University (Nepal), Westcliff University (USA), University of the West England (UWE) as a visiting Faculty of Financial Management, Financial Derivatives and Risk Management and Investment Analysis. Email: gplbhatta@gmail.com

** Ms. Mishra is an MBA graduate from Southwestern Oklahoma State University (USA) and an MA (Economics) from Tribhuvan University (Nepal), also lecturer of micro and macroeconomics in Kings College, Nepal and freelance researcher in public and financial economics. Email: anumishra55@gmail.com 


\section{INTRODUCTION}

Higher economic growth is one of the goals (out of 17 goals) of sustainable development goals (SDGs) outlined by the United Nations to be achieved by member countries by 2030 (United Nations, 2018). Massive investment in infrastructure, technological innovation and development, machine learning, artificial intelligence, human capital, and environmental protection is required to boost up economic activities towards achieving this goal. Taxation and public borrowing are two major sources of funds to finance such investment requirements. Since taxation creates distortionary effects on economic growth, gives excess burden to the public by increasing the cost of living, and reduces the purchasing power of people; it is less popular among the policymakers (Barro, 1979). Therefore, public debt is seemed to be only feasible option to finance government expenditure and other development projects if the country lacks funds.

Theories of public financing provide contradictory opinions on the utilization of debt resources in order to enhance economic growth. On the one spectrum, there are classical and Ricardian theories that cautiously argue that public debt is a burden to future generations and long-term debt drags investments (Ashfaq \& Padda, 2019). The Keynesian argument, on the other side, encourages the reasonable stock of public debt in the short run to accelerate investment and employment opportunities. Neoclassical economists like Modigliani (1961), Diamond (1965), and Saint-Paul (1992) hold the view that an increasing level of public debt will have a negative impact on economic growth (Afonso \& Jalles, 2013). Thus, debt financing is a double-edged sword that might be instrumental in order to achieve a higher level of growth with cautious utilization. Otherwise, debt overhang and crowding out are the negative outcomes of channelizing resources through public debt (Akram, 2011).

In order to avoid negative consequences of debt financing, empirical studies are focused to quantify public debt ratio that can be judged as optimal. The results of the studies indicate that moderate public debt levels stimulate economic growth, while diminished economic growth characterizes debt ratios beyond the determined threshold (Scherjon, 2017). Some studies pointed out the stationary debt-to-GDP level of the nation mimics the optimum that implies that when shock to debt-to-GDP level occurs, budgetary surpluses ensure that the debt level will revert to the initial debt level (Da Costa, 2010). In contrast, some studies on optimum public debt ratios are directed to maximize social welfare like Aiyagari and McGrattan (1998). However, most recent papers search optimal public debt ratio as the ratio for which economic growth is maximized. The existence of such an economic growth maximizing public debt level implies the non-linear debtgrowth relationship, where issuing additional debt beyond the optimum debt 
threshold causes a reduction in GDP (Scherjon, 2017). Accordingly, this paper seeks an optimal debt GDP ratio that maximizes the economic growth of Nepal.

Nepal experienced not a very long history of borrowing domestically and internationally to meet her development requirements. The first internal loan raised by the Government of Nepal was in 1962, after 11 years of its budget formulation in 1951. External borrowing, on the other hand, shows the historical recording since 1963, former Union for the Soviet Socialist Republic (USSR) being the first foreign creditor of Nepal. As per the Economic Survey (2020), the current public debt ratio is hovering around 30-40 per cent. In 1995, the ratio reaches its highest peak at 65.53 per cent.

The federal structure of the government and rising aspirations of the people further compelled governments at the various levels to mobilize enough resources. Despite limited tax base and domestic borrowing, Nepal is heavily relying on international resources particularly in external borrowing, which might be both costly and risky comparing to domestic borrowing. Further, a developing country like Nepal must expose a higher level of foreign exchange, sovereign, and country risk in the external loan. Hence, public debt is crucial for economic growth and development especially for the countries with a lack of savings and investments like Nepal (Rahman, Ismail, and Ridzun, 2019).

The available empirical studies on the effect of public borrowings on economic growth provide mixed results contingent on the amount of debt and its purposes. The benchmark of public debt to GDP ratio has been claimed by Reinhart, Reinhart, and Rogoff (2015) which should be at most 90 per cent, the economy will be able to grow positively when the debt level is below the threshold. Beyond the threshold, public debt will cause an adverse effect on an economy. Many other studies in developed and developing economies, however, contradict the 90 per cent benchmark and ranges from 15 per cent (Butkus \& Seputiene, 2018) up to 2000 per cent (Pegkas, 2000). Hence, the fundamental objective in this context is to find public debt and economic growth relationship and identify any such threshold ratio in Nepal.

To the best of our knowledge, no study has focused on the determination of a threshold point beyond which the incurrence of additional debt injures economic growth in $\mathrm{Nepal}^{1}$. Therefore, this study aims to determine the threshold point

1 While there is a substantial body of research exploring the interconnection between debt and growth in both developed and emerging countries, few papers have looked at this link in the context of Nepal. Ra, Rhee \& Hahm (2005) estimated an optimal target portfolio of sovereign debt for Nepal that minimizes long-term financing cost. The study applied the traditional mean-variance efficient frontier approach to simulate the portfolio risk and return. The findings of the study reveal that Nepali economy needs to increase longer-term domestic borrowing 
beyond which public debt begins to hamper Nepal's economic growth prospects. The findings of the study are expected to guide policymakers in formulating and designing optimal debt strategy that stimulates and is conducive for the economic growth of Nepal.

Accordingly, this paper complements existing empirical evidence on the relationship between economic growth and public debt in developing economies using Nepal as a case study. By doing so, it seeks to fill gaps in the existing literature. First, the various ranges of growth maximizing public debt thresholds show the literature on the optimal public debt remains far from robust. There is a possibility that the growth-inhibiting effects of public debt can be outweighed by corresponding growth-promoting variables achieved through public spending. With the presence of inconsistent empirical evidence on the debt-growth relationship, the literature on growth maximizing public debt is still incomplete. This emphasizes the importance of further empirical analysis of growthmaximizing public debt thresholds. Second, most of the studies in the literature have estimated the linear association between public borrowing and GDP growth. The present study aims to find out optimal growth maximizing public debt ratio using autoregressive distributive lag (ARDL) technique to examine the possibility of a non-linear relation between debt and growth in the context of Nepal.

There is a long debate on the relationship between public debt and economic growth. Some argue that government borrowing helps to enhance economic growth and has a positive effect on disposable income, aggregate demand and overall output (Elmendorf \& Mankiw, 1998). On the contrary, a high level of public debts is deleterious for growth, especially after a certain threshold has been reached (Chechertia \& Rother, 2010). Policymakers, therefore, are interested to analyse the impact of the high level of public debt that might negatively influence economic growth and try to reduce the public debt as a tool of fiscal consolidation. This paper is an attempt to investigate the relationship in the context of Nepal.

The rest of the paper is organized as follows. Section II reviews theories and empirical studies on the linkage between public debt and economic growth along with stylized facts of such relationships in the context of Nepal. The data, variable, and empirical methodology has been discussed in section III. Section IV

instruments and maturity structure of borrowing instruments should be simplified. Based on descriptive statistics, Battarai (2013) assessed public debt ratio with other macro-economic indicators using data from 1975/76 to 2010/11. The study was focused on to report the share of domestic debt and external debt on GDP on periodical basis, periodical growth rates and inflation. The study reports the growth of the economy is low despite increased budget and public debt level. 
covers empirical results. Finally, section V provides concluding remarks with relevant recommendations.

\section{THEORETICAL UNDERPINNINGS AND EMPIRICAL WORKS ON PUBLIC DEBT-ECONOMIC GROWTH RELATIONSHIP}

In this section, this paper briefly reviews main theories formulated overtime on the economic effects of public indebtedness followed by some empirical work on the relationship between public debt and economic growth. Three major views, namely the classical one, the Keynesian one, and the neoliberal (monetarist economists and representatives of the school of rational expectations) are considered. Further, an overview of public debt structure along with stylized facts has been discussed to understand the dynamics of public indebtedness and linkage with output growth in Nepal.

\subsection{Overview of the main theories on the economic effects of public indebtedness}

The classical doctrine is faithful to the "Laissez fair" principle and regulatory action of the market forces, thus, predominantly denies the role of public borrowing in economic growth (Bilan, 2016). Classicist allow state to play the role of ensuring the smooth functioning of economic relations without intervening in the economy. Smith (1904) denies the states right to incur debt arguing that indebtedness delays the natural progress of a nation towards wealth and prosperity. It has been further argued that resources, which would receive productive destinations in the private sector, are diverted by the state to cover its unproductive expenditure, thus being wasted without any hope of future reproduction. The negative effects of indebtedness on the accumulation of productive capital in the economy are also documented by Ricardo (2005).

Altering the very liberal assumptions and principles that classical economists rely upon, Keynesians attaches great importance to the state whose intervention in economy and society are no longer blamed but are called to implement the actions of the market and to correct its imperfections. Keynesians accepted the extension of the scope of the state to avoid negative effects of public expenditure (at the funding of which public debt contributes) and contributes to economic growth and development. Further, public authorities are assigned role to counter disturbances in a social and economic phenomenon that gives the new identity of public borrowing to correct imbalances and ensure an upward evolution in the economy. Keynesian contributions in this regard are highly appreciated in designing demand-side fiscal policies for re-launching the economy in recession or stimulating balanced economic growth (Bilan, 2016). 
The economic liberalism resurged in the 1970s in a powerful manner emerging with the representatives of the neoliberal doctrine marked a new change by reviving precepts of the "good" classical doctrine and disapproving of the state's indebtedness. According to the proponents of the neoliberal doctrine, "Whatever the relative position of the country in question, increasing deficits express the promise of future difficulties ... and reduced welfare (Landais, 1998)". The main argument that justifies the disapproval of the State's borrowing arises from the negative effect of public borrowings called the 'crowding-out effect'. The crowding-out effect broadly assumes that the demand for loanable funds increases when public authorities indebt themselves by raising public loans which results in an increase in the market interest rate. This, in turn, reduces private investments and so private capital funds "flee" towards the public sector to serve public expenditure financing. Overall, the monetarist emphasizes that the chances of producing a positive effect on GDP growth produced on account of promoting debt-financed budget deficits become very low, even null.

However, Barrow (1979), which represents the school of rational expectations, expressed a different view which coincides with the Ricardian Equivalence thesis. The study challenged Keynesian reasoning and claims debt neutrality on the grounds of the equivalence, in terms of their effects between the financing of a certain amount of public spending through the ordinary alternative of taxes or by public borrowings.

Accordingly, the classical (liberal) arguments and Keynesian ones are blended in a so-called conventional view (Elmendorf and Mankiw, 1998) that distinguishes between the effects of public debt on economic growth over the short-term and over the medium or long-term. The framework of analysis is Keynesian in nature form short-term perspective. The level of demand, thus, determines the supply of goods and services, therefore, the output, which at its turn can be influenced by public borrowings to finance increased budget deficits. Hence, the public indebtedness can prove to be beneficial for the economy over the short-term, especially when the economy is in a recession or confronted with weak growth rates and when the actual GDP is well below its potential level. On the contrary, the framework of analysis is classical in nature from the perspective of a longer period of time. The impact of demand becomes less relevant and the indebtedness of public authorities, to finance budget deficits, is considered to result in the reduction of total (public and private) saving, the increase of the interest rate, decrease of investments, and the reduction of capital stock. Thus, its effects on economic growth appear to be mostly negative ones.

Thus, the relevance of public debt for policymakers to consider positive effects on economic growth, or limit any possible negative effects, are of threefold aspects. First, public indebtedness must not become common practice. Public borrowing 
would be productive in those situations in which the economy is confronted with an unusual phenomenon requiring large-scale government interventions and important financial (public) resources. Second, the financial resources raised by means of borrowing should be used on those destinations which allow creating added value in the economy, over the medium and long-term, thus ensuring the prerequisites for future repayment, without major difficulties, of resulting public debt. Third, the dimension of public debt (the rate at which public debt is accumulated, and the overall size of debt) needs to be considered as well. When public debt is large or accumulates at a very fast pace, the likelihood of possible side effects to occur increase, that in turn, may have negative effects in economic growth rate.

\subsection{Empirical works}

Most of the empirical works revealed a linear relationship between public debt and economic growth. This relationship can further be classified into positive, negative, and insignificant one. A positive linear correlation implies that the economy is able to grow as the debt level increases. Investment in infrastructure, human capital, technology requires financing from debt as well, which enhances economic growth. On the other hand, a linear negative relationship indicates that economic growth is declining when the country increases its debt level. If it happens, many projects need to be postponed as additional debt will only lead to the slowdown of economic growth.

Most of the studies conducted from 2017 to 2019 those discussed the relationship between public debt and economic growth demonstrated a significant negative relationship between the two series. Firstly, this relationship is consistent with the conventional view of debt (Elmendorf and Mankiw, 1998), in which there will be a crowding-out effect on the private investment when the economy is facing a high debt problem (Bahal, Raissi, \& Tulin, 2018; Chudik et al., 2017; De Vita, Kim, Ha, and Kim, 2017; Shahor, 2018). The effect is valid in the long run. The government borrowing in the loanable fund market exerts upward pressure on the interest rate which will demotivate the investors from investing in the country. If this condition persists, there will be an adverse effect on economic growth in the long run.

Secondly, the lower economic growth that is caused by high public debt can also be explained theoretically using the debt overhang (Krugman, 1988). Debt overhang happens when the highly indebted countries have a lower present value of the national income relative to their total accumulated debt (Burhanudin et al., 2017; Ewaida, 2017; Snieska \& Bursakaitiene, 2018). One possible reason might be the inefficiency of the countries to manage borrowed funds (Schkolnyk \& Koilo, 2018). Instead of channeling the borrowed funds to productive purposes, 
the governments choose to use the funds to pay previous debts, or to finance operating expenditures which are normally non-productive in nature. Consequently, these funds, which are normally not being used for productive purposes will not create significant value added to the economy, thus contributing to lower economic growth.

Thirdly, lower economic growth that is caused by high public debt can also be explained through the overlapping generation's model (Blanchard, 1985; Diamond, 1965; Modigliani, 1961), where the increase in public debt will be partly used up national savings that were meant for the future generations. A reduction in the level of national savings will force the interest rate to increase thus demotivate incoming investors. Lower investments will result in lower capital accumulation, leading to lower economic growth.

On the other hand, public debt can also contribute to higher economic growth, for instance, Malaysia (Burhanudin et al., 2017) and European countries (GomezPuig \& Sosvilla-Rivero, 2017a). Theoretically, it can be explained by using the conventional view of debt by Elmendorf and Mankiw (1998). Even though this view has a negative perspective on public debt to economic growth, it also has a positive standpoint on the two series. An increase in public debt will help to stimulate aggregate demand and output, among others via employment generation and productive investment. However, this relationship can only apply in the short run. If it continues to increase in the long run, the effect can switch to becoming negative. Therefore, it is important for the government to be alert to the debt threshold that can switch the debt's effect from positive to negative.

In addition, when public debt can affect economic growth in both positive and negative directions, the non-linear relationship appears. The literature captured the threshold effect by including square term of debt in the growth equation (Ahlborn \& Schweickert, 2016; Butkus \& Seputiene, 2018) or by conducting the panel smooth transition regression (Chen, Yao, Hu \& Lin, 2017; Karadam, 2018).

While testing the existence of non-linear relationships, this relationship exists in the European countries (Brida, Gomez \& SeiJas, 2017; Gomez-Puig \& SosvillaRivero, 2017; Pegas, 2018, 2019) and emerging economies (Schkolnyk \& Koilo, 2018).On the contrary, it is also found that non-linear relationship does not exist in Spain (Esteve \& Taramit, 2018) and other countries (Arcabi et al.,2018; Kim et al., 2017). The Reinhart-Rogoff hypothesis argued that public debt can positively affect economic growth if the debt to GDP level is lesser than 90\% (Reinhart, Reinhart, \& Rogoff, 2015). Once the debt-to-GDP is beyond the threshold; the effect changes to negative. Empirically, the evidence from previous literature demonstrated that the debt-to-GDP threshold for all countries is not necessarily 
90\%. The threshold can range from $15 \%$ (Butkus \& Seputiene, 2018) up to 2000\% (Pegkas, 2018).

The studies, those found the threshold to be $90 \%$ and above, were conducted in Lebanon (Taher, 2017), Israel (Shahor, 2018), and Greece (Pegkas, 2018, 2019). The debt level that is beyond $90 \%$ of the GDP indicates that the countries are among the highly indebted countries. In this case, these countries may not be able to pay back the debt within the stipulated time period. In order to limit the default risk, the risk premium is added to the interest rate on public debt, leading to the high cost of borrowings. Indirectly, it distorts the economic growth once the threshold is met through the crowd-out effects on private investments.

There were also studies that found the threshold to be lower than 50\%. Among them were the European countries (Gómez-Puig \& Sosvilla-Rivero, 2017) and advanced economies such as Belgium, Canada, the United Kingdom, and the United States (Lee, Park, Seo, \& Shin, 2017). For these high-performing economies, the debt threshold is lower due to the lack of investments since the investors fear that the governments will impose higher taxes to finance the debt. As a result, the investors would prefer to channel their investments into other developing economies that costs lower to run a business.

Based on the above findings, it cannot be concluded that the debt-to-GDP threshold for the advanced economies is below 50\% while for the highly indebted countries is $90 \%$ and above. Besides, the findings from Reinhart \& Rogoff (2010) may not be true for all economies since the threshold reported by other researchers varied. Hence, no mutual consensus has been observed on the right threshold for each country or group of economies. The threshold for each country depends on their current economic situation, the period of studies, the method and the proxies used to test the relationship. Countries such as Lebanon and Greece that have a debt threshold of more than $90 \%$ should start in reducing their public debt level in order to ensure greater economic prosperity in the future. Further increase in public debt will not only burden the current generation due to an increase in taxation and reduction in investments.

\section{DATA, ESTIMATION AND METHODOLOGICAL ISSUES}

This section briefly describes the data, variables, model, and methodological issues. The main objective of this paper is to determine the causal effect of public debt on economic growth. By doing so, it will help to identify the growth maximizing public debt to GDP ratio in the context of Nepal.

Accordingly, the analysis involves estimating a model that relates economic growth with public debt and other variables. The dependent variable, thus, is the real gross domestic product (RGDP). Along with public debt as an independent 
variable, other control variables are included to examine the non-linear impact of government debt on the economic growth of Nepal. A bivariate quadratic growth equation has been estimated consistent with Checherita-Westpal and Rother (2012) to confirm whether a non-linear relationship between growth and public debt exists.

The debt growth relationship is estimated with ordinary least square (OLS) regression with several specifications that differ in the incorporated control variables and estimation techniques. The baseline model is specified in equation 3.1 .

$$
\text { growth }_{\mathrm{t}}=\beta_{0}+\beta_{1} \text { debt }_{\mathrm{t}}+\beta_{2} \text { debt }_{\mathrm{t}}^{2}+\text { control variables }+\varepsilon_{\mathrm{t}} \quad \ldots . \text { (3.1) }
$$

Where, growth $\mathrm{t}_{\mathrm{t}}$ is the equation's dependent variable and reflects the economic growth rate expressed in term of real GDP and debt $_{t}$ is public debt as a per centage of GDP. Other control variables such as domestic savings, trade openness, population, and gross fixed capital formation are included to improve the model diagnostics. The explanatory variables are expressed as per centages of GDP. The discussed non-linearity of the relationship is captured by including the squared terms of public debt (Checherita-Westpal and Rother, 2012; Jernej, Aleksander \& Miroslav, 2015). $\beta_{0}$ reflects the constant in the model and $\varepsilon_{\mathrm{t}}$ is the error term of the equation which contains non-included variables affecting economic growth. The coefficients of interest are $\beta_{1}$ and $\beta_{2}$ as these reflect the effect of public debt on economic growth. According to the literature, the expected coefficient of debt is positive and debt 2 should have a negative sign. These signs indicate the concave non-linear relationship between public debt and economic growths where modest debt level encourages boosting the growth and higher level of debt adversely affect the growth.

The control variables used in this study are standard variables found to be statistically significant drivers of the economic growth in literature (ChecheritaWestpal \& Rother, 2012; Panizza \& Presbitero, 2013; Wright \& Grinade, 2014; Romer, 2012). The inclusion of these variables enables us to determine whether public debt affects economic growth while taking into accounts the alternative growth affecting factors. The control variables included in the study for estimating models with their reference sources are presented in Table 3.1. 
Table 3.1: Control variables: specifications and sources ${ }^{2}$

\begin{tabular}{|c|c|c|}
\hline Variables & Specification & Study \\
\hline $\begin{array}{l}\text { Gross fixed capital } \\
\text { formation, Domestic savings, } \\
\text { and population growth }\end{array}$ & $\begin{array}{l}\text { Primary drivers of economic } \\
\text { growth according to } \\
\text { prominent study of Solow }\end{array}$ & $\begin{array}{lr}\text { Romer } & (2012), \\
\text { Mupunga } & \& \quad \text { Roux } \\
(2015) & \end{array}$ \\
\hline Trade openness & $\begin{array}{l}\text { The beneficial character of } \\
\text { trade and international } \\
\text { competitiveness of a country }\end{array}$ & $\begin{array}{l}\text { Checherita-Westpal \& } \\
\text { Rother, (2012) }\end{array}$ \\
\hline
\end{tabular}

It should, however, be noted that the purpose is not to assess the drivers of economic growth but to use the link between public debt and growth to determine the optimal growth-maximizing public debt threshold ${ }^{3}$.

The relationship between public debt and economic growth and the potential existence of growth maximizing debt-ratio is examined for the period 1976-2019. The annual time series data has been collected from national and international sources. Most of the data has been taken from Economic Surveys published by the Government of Nepal, Handbook of Government Finance Statistics and Quarterly Economic Bulletin published by Nepal Rastra Bank, and World Bank databases. Table 3.2 reports the applied symbols, descriptions, and data sources of included variables (3.1).

2 The choice of the variables for empirical specifications is based on the previous literature on identifying the debt-growth relationship and optimum public debt threshold. Panizza \& Presbitero (2012) and Cecchetti et al. (2011) controlled the model with population growth, national gross savings, and trade openness along with other variables. Wright \& Grenade (2014) experimented with control variables labor input, capital stock, government consumption, trade openness among others. Mupunga \& Roux (2015) included domestic savings and gross capital formation in the model including other variables. Ashfaq \& Padda (2020) has controlled the model using variables population growth, trade openness, gross fixed capital formation and so on.

3 We also attempted to control for the size of the government as proxies by government consumption as a share of GDP, impact of monetary policy represented by the banking credit to private sector, government fiscal policy instrument, i.e. government budget balance, inflation and proportion of primary school students with population (as proxy of education) . These variables generally turn out to be statistically insignificant when most of the other regressors are included. Moreover, their inclusion or exclusion has no noticeable effects on the other regression coefficients. 
Table 3.2: Abbreviations, descriptions, expected sign and sources of the included variables

\begin{tabular}{|c|c|c|c|c|}
\hline Symbol & $\begin{array}{l}\text { Variable } \\
\text { name }\end{array}$ & Description & $\begin{array}{l}\text { Expected } \\
\text { sign }\end{array}$ & Source \\
\hline RGDP & $\begin{array}{l}\text { Economic } \\
\text { growth }\end{array}$ & $\begin{array}{l}\text { Yearly growth } \\
\text { rate of real GDP }\end{array}$ & $\begin{array}{l}\text { Dependent } \\
\text { variable }\end{array}$ & $\begin{array}{l}\text { Economic surveys published by } \\
\text { Ministry of Finance, GON, FY } \\
\text { (1986/87 to FY 2019/20), } \\
\text { World Bank, } \\
\text { https://databank.worldbank.org }\end{array}$ \\
\hline PDR & $\begin{array}{l}\text { Public Debt- } \\
\text { to-GDP ratio }\end{array}$ & $\begin{array}{l}\text { Federal } \\
\text { government } \\
\text { gross debt as } \\
\text { ratio of GDP }\end{array}$ & + & $\begin{array}{l}\text { Economic surveys published by } \\
\text { Ministry of Finance, GON, FY } \\
\text { (1986/87 to FY 2019/20), } \\
\text { A Handbook of Government } \\
\text { Finance Statistics, Nepal Rastra } \\
\text { Bank, vol, IV. June } 2016\end{array}$ \\
\hline PDR2 & $\begin{array}{l}\text { (Public Debt- } \\
\text { to-GDP } \\
\text { ratio) } 2\end{array}$ & $\begin{array}{l}\text { Federal } \\
\text { government } \\
\text { gross debt as } \\
\text { ratio of GDP }\end{array}$ & - & Own calculations \\
\hline GFCI & Investments & $\begin{array}{l}\text { Gross Fixed } \\
\text { Capital } \\
\text { Investment }\end{array}$ & + & $\begin{array}{l}\text { Economic surveys published by } \\
\text { Ministry of Finance, GON, FY } \\
\text { (1986/87 to FY 2019/20), }\end{array}$ \\
\hline TROPEN & $\begin{array}{l}\text { Trade } \\
\text { Openness }\end{array}$ & $\begin{array}{l}\text { Imports of } \\
\text { goods and } \\
\text { services plus } \\
\text { exports of goods } \\
\text { and services, } \\
\text { both as ratio of } \\
\text { GDP }\end{array}$ & + & $\begin{array}{l}\text { Economic surveys published by } \\
\text { Ministry of Finance, GON, FY } \\
(1986 / 87 \text { to FY 2019/20), } \\
\text { Quarterly Economic Bulletin, } \\
\text { Nepal Rastra Bank, Mid- } \\
\text { January, 2019, 53(2) }\end{array}$ \\
\hline POP & $\begin{array}{l}\text { Population } \\
\text { growth }\end{array}$ & $\begin{array}{l}\text { Yearly } \\
\text { population } \\
\text { growth rate }\end{array}$ & - & $\begin{array}{l}\text { World Bank, } \\
\text { https://databank.worldbank.org }\end{array}$ \\
\hline DSAV & Savings & $\begin{array}{l}\text { Domestic } \\
\text { savings, as per } \\
\text { centage of GDP }\end{array}$ & - & $\begin{array}{l}\text { Economic surveys published by } \\
\text { Ministry of Finance, GON, FY } \\
\text { (1986/87 to FY 2019/20), }\end{array}$ \\
\hline
\end{tabular}

An Autoregressive Distributed Lag (ARDL) approach has been used to estimate the model proposed by Pesaran et al. (2001). The link between debt and growth could be driven by the fact that low economic growth can lead to high levels of public debt (Krugman, 2010). Traditionally, the cointegration approach has widely been used to establish long-run relationship among certain variables. The method of cointegration requires that variables be integrated of the same order. If 
the order of integration among variables is not the same, then long-run relationship among them cannot be established.

\section{EMPIRICAL RESULTS}

The main objective of this paper is to estimate the growth-maximizing public-debt to GDP ratio by testing alternative models to conform Laffer-curve type relationships in the context of Nepal. Accordingly, this section provides the results of the empirical analysis that consists of (i) statistical properties of the variables, (ii) test of stationarity (iii) Autoregressive Distributed Lag (ARDL) estimates (iv) optimum growth-maximizing public debt threshold, and (v) robustness checks.

\subsection{Statistical properties of the variables}

Table 4.1 includes the descriptive statistics of the variables included in the model over time 1976-2019 periods. The mean, median, maximum, minimum, standard deviation and number of observations of each variable are reported for each variable. The variables are mainly measured as a per centage of GDP; the only exception is the population growth rate. The discussion of the descriptive statistics is restricted to the primary variable of interest, namely, real GDP and public debt ratio.

Table 4.1: Descriptive statistics

\begin{tabular}{|l|r|r|r|r|r|r|}
\hline Variables & \multicolumn{1}{|c|}{ Mean } & Median & Maximum & Minimum & Std. Dev & Observation \\
\hline RGDP & 4.42 & 4.52 & 10.03 & -1.50 & 2.44 & 44 \\
\hline PDR & 39.83 & 36.89 & 65.53 & 6.22 & 18.82 & 44 \\
\hline GFCI & 20.82 & 20.04 & 36.99 & 14.04 & 4.77 & 44 \\
\hline DSAV & 11.60 & 11.45 & 18.97 & 4.06 & 2.58 & 44 \\
\hline POP & 1.73 & 2.16 & 2.76 & -0.26 & 0.84 & 44 \\
\hline TROPEN & 31.35 & 34.99 & 43.82 & 17.81 & 8.25 & 44 \\
\hline
\end{tabular}

Historically, from 1976 until 2019, Nepal's real GDP averaged 4.42 per cent, reaching an all-time high of 10.03 per cent in 1981. Moreover, GDP growth has been positive except in one year of the 1980s. The lowest economic growth rate in the sample period is observed in the year 1980 ( -1.50 per cent). The country was facing huge political turmoil in the year, especially the referendum announced by then regime and around the region at that time along with the fiscal disorder. The country has witnessed maximum growth of 10.03 per cent immediately next year (in 1981) due to base effect and economic reforms introduced by the government. 
RGDP

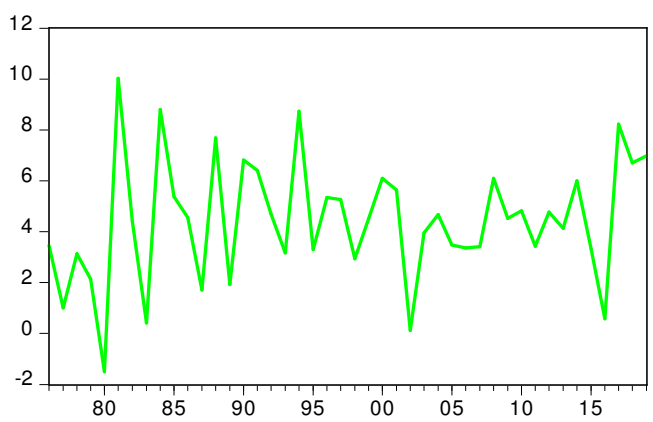

PDR

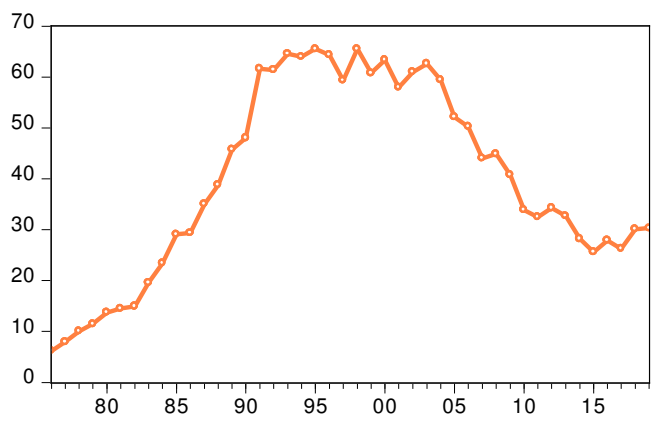

Figure 4.2: Trend in public debt in Nepal

Figure 4.1: Trend in economic growth of Nepal

Public debt to GDP ratio during the period has shown a severe increase over the period 1976-1995 and then has a declining trend until 2015. The average ratio of the period is 39.83 per cent which reached 65.53 per cent in 1995 . The minimum public debt ratio has been observed 6.22 per cent at the initial periods to raise funds for financing expenditure by the Government of Nepal (GoN). Government borrowing has been declining after 1995 due to fiscal austerity measures to revitalize the economy and deteriorating capacity of GoN to enhance capital expenditure in the conflict era.

\subsection{Correlation matrix}

The correlation matrix reported in Table 4.2 shows that public debt is positively correlated with real GDP growth in Nepal. The correlation coefficient between public debt to GDP ratio and real GDP has been observed 0.13, as expected from theoretical perspective (Table 3.2). Intuitively, debt is highly and positively correlated with debt 2 , which is confirmed by the matrix. In general, the obtained correlation matrix indicates that when public debt increases economic growth it also increases in Nepal. As observed from the matrix, gross fixed capital formation and domestic savings have a correlation coefficient of 0.33 , which is not much higher as expected.

Table 4.2: Correlation matrix

\begin{tabular}{|l|r|r|r|r|r|r|r|}
\hline Variables & \multicolumn{1}{|l|}{ PDR } & \multicolumn{1}{l|}{ RGDP } & TROPEN & GFCI & \multicolumn{1}{l|}{ POP } & \multicolumn{1}{c|}{ DSAV } & PDR_2 \\
\hline PDR & 1.00 & 0.13 & 0.54 & 0.10 & 0.11 & 0.12 & 0.98 \\
\hline RGDP & 0.13 & 1.00 & 0.21 & 0.21 & 0.05 & 0.27 & 0.09 \\
\hline TROPEN & 0.54 & 0.21 & 1.00 & 0.74 & -0.51 & 0.30 & 0.47 \\
\hline GFCI & 0.10 & 0.21 & 0.74 & 1.00 & -0.36 & 0.33 & 0.01 \\
\hline POP & 0.11 & 0.05 & -0.51 & -0.36 & 1.00 & -0.57 & 0.22 \\
\hline DSAV & 0.12 & 0.27 & 0.30 & 0.33 & 0.21 & 1.00 & 0.17 \\
\hline PDR_2 & 0.98 & 0.09 & 0.47 & 0.01 & 0.22 & 0.48 & 1.00 \\
\hline
\end{tabular}


Further, all the control variables have expected correlations with real GDP growth. All the control variables viz. trade openness, population growth, credit to the private sector, investments, and domestic savings are positively correlated with economic growth in line with the literature.

\subsection{Scatter plot}

The scatter plot of Figure 4.3 confirms the positive correlation between debt and real economic growth. The figure further supports the Ordinary Least Square (OLS) regression slope coefficient of 0.017 , which implies that a 10 per cent increase in public debt ratio results in a 0.17 per cent increase in real GDP ${ }^{4}$. This suggests that higher debt ratio is associated with a higher economic growth.

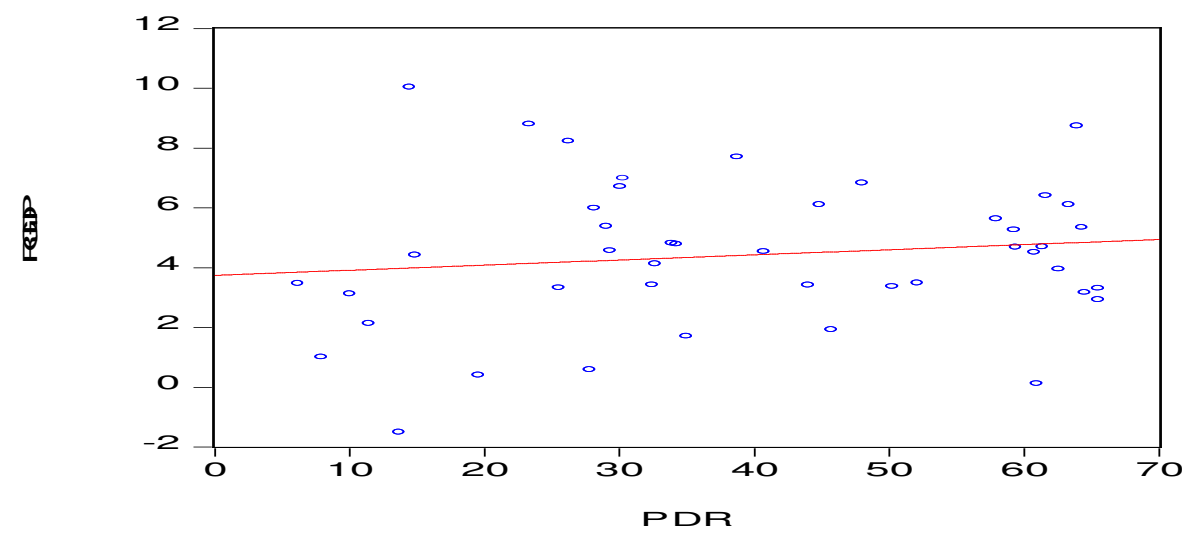

Figure 4.3: Scatterplot of the debt-to-GDP ratio and RGDP

The observed positive relation is an indication only of preliminary evidence, as the presence of an endogeneity issue might bias the result. Therefore, the causal claims on the exact debt-growth relationships cannot be made. The scatter plot does not include control variables or reverse causality or non-linearity into account.

\subsection{Unit root test}

Time series data are often non-stationary and incase of non-stationary in variables OLS estimations become spurious. Thus, to avoid spurious results, this study applies a unit root test to check whether every variable is stationary or not.

4 The univariate debt-growth model has been examined with the OLS estimation. The OLS regression without control variables has been specified as $\operatorname{rgdp}_{t}=\beta_{0}+\beta_{1} \operatorname{pdr}_{t}+\varepsilon_{\mathrm{t}}$. The result reports that estimated equation coefficients of $\beta_{0}=3.714$ (t-value $=4.28$ ) and $\beta 1=0.017$ ( $\mathrm{t}$ value $=0.86$ ). 
Table 4.3 provides the results of the unit root test of variables selected for the study using ADF statistic at level data and first difference (trend and intercept) .The decision criteria involve comparing the computed Tau values with the MacKinnon critical values for the rejection of a hypothesis for a unit root. If the computed tau (ADF) statistic is less negative (i.e. lies to the right of the MacKinnon critical values) relative to the critical values, we do not reject the null hypothesis of non-stationarity in time series variables.

Table 4.3: Unit root tests

\begin{tabular}{|l|l|l|l|l|l|}
\hline \multicolumn{3}{|c|}{ Level } & \multicolumn{3}{c|}{$\begin{array}{l}\text { First } \\
\text { Difference }\end{array}$} \\
\hline Variable & Intercept & $\begin{array}{l}\text { Trend \& } \\
\text { Intercept }\end{array}$ & Intercept & $\begin{array}{l}\text { Trend \& } \\
\text { Intercept }\end{array}$ & Decision \\
\hline RGDP & $-7.82 * * *$ & $-7.94 * * *$ & ------- & ------- & $\mathrm{I}(0)$ \\
\hline PDR & -1.86 & -0.98 & -2.41 & $-6.57 * * *$ & $\mathrm{I}(1)$ \\
\hline PDR2 & -1.66 & -0.87 & $-2.70 *$ & -3.03 & $\mathrm{I}(1)$ \\
\hline PSCR & 3.55 & 0.73 & $-6.91 * * *$ & $-8.55^{* * *}$ & $\mathrm{I}(1)$ \\
\hline GFCI & 1.45 & -0.20 & -2.33 & -2.90 & $\mathrm{I}(1)$ \\
\hline DSAV & $-2.91 *$ & -2.85 & ------- & ------- & $\mathrm{I}(0)$ \\
\hline POP & -1.29 & -2.15 & -2.38 & -2.38 & $\mathrm{I}(1)$ \\
\hline TROPEN & -0.97 & -1.89 & $-3.09 * *$ & -3.04 & $\mathrm{I}(1)$ \\
\hline
\end{tabular}

Note: *Significant at 10 per cent level, **at 5 per cent level and ***at 1 per cent level

The ADF results show that there is a mixture of both level stationary $\mathrm{I}(0)$ and first difference stationary variables I(1) at a five per cent level of significance. In this case, there is an obvious question that whether there is any possibility for the existence of a long-run equilibrium relationship among the given set of variables.

\subsection{ARDL approach of co-integration}

The cointegration test was conducted by using the autoregressive distributed lag (ARDL) procedure developed by Pesaran et al. (2001). In this study, the ARDL cointegration approach is applied because it has some advantages in comparison with other cointegration methods. Unlike other cointegration techniques, the ARDL does not impose a restrictive assumption that the variables understudy must be integrated of the same order. In other words, we can test for cointegration among variables regardless of whether the underlying regressors are integrated of order one I (1) or order zero I(0). Secondly, while other cointegration techniques are sensitive to the size of the sample, the ARDL test is suitable even if the sample size is small. Thirdly, the ARDL approach generally provides unbiased 
estimates of the long-run model and valid statistics even when some of the regressors are endogenous. Accordingly, the ARDL model for this study has been estimated as specified in equation 4.1 .

$$
\begin{aligned}
& \Delta r g d p_{t}=\beta \mathrm{o}+\sum_{i=1}^{p} \beta_{1} \Delta r g d p_{t-i}+\sum_{i=1}^{q 1} \beta_{2} \Delta p d r_{t-i}+\sum_{i=0}^{q 2} \beta_{3} \Delta p d r_{-} 2_{t-i}+ \\
& \sum_{i=0}^{q i} \delta_{i} \Delta X_{t-i}+\Upsilon_{1} r g d p_{t-1}+\Upsilon_{2} p d r_{t-1}+\Upsilon_{3} p d r_{-} 2_{t-1}+\Upsilon_{i} X_{t-1}+\varepsilon_{t}
\end{aligned}
$$

Where, $\Delta$ denotes the first difference operator, $\beta o$ is the drift component and $\varepsilon_{\mathrm{t}}$ is assumed to be the white noise process. Note that $\mathrm{p}$ is the lags of the dependent variable and qi is the number of lags of the $\mathrm{i}$-th explanatory variables.

Accordingly, the first stage of the ARDL model approach involved the F-test in which the asymptotic distribution of the F-statistics is not standard under the null hypothesis of no cointegrating relationship between the examined variables, irrespective of whether the explanatory variables are purely $\mathrm{I}(0)$ or $\mathrm{I}(1)$. If the Fstatistics exceeds the lower and upper critical bound, there is no statistical reason to accept the null hypothesis. Next, the ARDL approach involves an estimation of the coefficients on the long-run cointegrating relationship and the corresponding error correction model (ECM). The lagged error correction term (et-1) derived from the error correction model is an important element in the dynamics of the cointegration system. The size and statistical significance of the error correction term measure the extent to which each dependent variable has the tendency to return to its long-run equilibrium.

The selection of lag is important to conduct the ARDL model as this model is very sensitive to the choice of an optimum lag length. This study applied unrestricted vector auto-regression (VAR) to estimate an appropriate model understanding the relationship of public debt to economic growth in Nepal. The unrestricted VAR provides criteria such as likelihood ratio (LR), final prediction error (FPE), Akaike's information criteria (AIC), Schwarz information criteria (SC), and Hannan Quin information criteria (HQ). The results of all the criteria are presented in Table 4.4 .

Table 4.4: Results of lag length selection criterion (unrestricted VAR model)

\begin{tabular}{|l|l|r|r|r|r|r|}
\hline Lag & \multicolumn{1}{|c|}{ LogL } & \multicolumn{1}{c|}{ LR } & \multicolumn{1}{c|}{ FPE } & \multicolumn{1}{c|}{ AIC } & \multicolumn{1}{c|}{ SC } & \multicolumn{1}{c|}{ HQ } \\
\hline 0 & -888.98 & NA & $2.26 \mathrm{e}+10$ & 43.70 & 43.99 & 43.81 \\
\hline 1 & -616.22 & 439.06 & 425929.4 & 32.79 & 35.13 & 33.64 \\
\hline 2 & -515.44 & 127.83 & 42153.65 & 30.26 & $34.65 *$ & 31.86 \\
\hline 3 & -437.64 & $72.10^{*}$ & $19420.63 *$ & $28.86^{*}$ & 35.29 & $31.20^{*}$ \\
\hline
\end{tabular}


The AIC, FPE, and HQ criteria suggested that the optimum lag length for this model is three, and SC criteria suggested the optimum lag two, so this study has estimated the ARDL model using a maximum of two lags.

In the light of the evidence of the time series being either stationary or first differences in stationary variables, a bound test has been conducted in the model. The estimated F-statistics is obtained from the estimates manage to reject the joint hypothesis of no-cointegration since it exceeds the lower and upper critical bound albeit at a one per cent significance level. This evidence permits us to proceed with estimating our empirical ARDL model. The results of the bound test are reported in Table 4.5 .

Table 4.5: Bounds test for co-integration

\begin{tabular}{|l|l|l|l|l|}
\hline F-Statistic & Lag Length & Significance Level & $\begin{array}{l}\text { Bound Critical } \\
\text { Values }\end{array}$ \\
\hline & & & $\mathrm{I}(\mathrm{O})$ & $\mathrm{I}(1)$ \\
\hline \multirow{2}{*}{13.45} & 2 & $10 \%$ & 2.188 & 3.254 \\
\cline { 3 - 5 } & & $5 \%$ & 2.591 & 3.766 \\
\hline & & $1 \%$ & 3.54 & 4.931 \\
\hline
\end{tabular}

Note: the lag length was selected based on the Schwarz criterion. The critical values are for $\mathrm{N}=45$.

Thus, with the help of bound test value, it has been concluded that there exists cointegration among the variables and long-run and short-run coefficients can be estimated.

The calculation of these estimated long-run coefficients is given by equation 4.2.

$$
\operatorname{rgdp}_{\mathrm{t}}=\delta_{1}+\delta_{2} \mathrm{pdr}_{\mathrm{t}}+\delta_{3} \mathrm{pdr}_{2 \mathrm{t}} \delta_{1}+\delta_{4} \text { tropen }_{\mathrm{t}}+\delta_{5} \mathrm{gfci}_{\mathrm{t}}+\delta_{6} \text { pop }_{\mathrm{t}}+\delta_{7} \mathrm{dsav}_{\mathrm{t}}+\epsilon_{\mathrm{t}}
$$

Finally, after confirming the long-run relationship, an error correction representation exists which is estimated from the following reduced form equation (4.3).

$$
\begin{aligned}
& \Delta \operatorname{rgdp}_{\mathrm{t}}= \\
& \sum_{\mathrm{i}=1}^{\mathrm{p}} \theta_{1} \Delta \operatorname{rgdp}_{\mathrm{t}-1}+\sum_{\mathrm{i}=1}^{\mathrm{q} 1} \varpi_{\mathrm{i}} \Delta \mathrm{pdr}_{\mathrm{t}-1}+ \\
& \sum_{\mathrm{i}=0}^{\mathrm{q} 2} \pi_{\mathrm{i}} \Delta \text { pdr }_{-} 2_{\mathrm{t}-1}+ \\
& \sum_{\mathrm{i}=1}^{\mathrm{q} 1} \tau_{\mathrm{i}} \Delta \operatorname{tropen}_{\mathrm{t}-1} \sum_{\mathrm{i}=1}^{\mathrm{q} 1} \varkappa_{\mathrm{i}} \operatorname{gfci}_{\mathrm{i}=1}^{\mathrm{q} 1} \phi_{\mathrm{i}} \Delta \text { pop }_{\mathrm{t}-1} \sum_{\mathrm{i}=1}^{\mathrm{q} 1} \psi_{\mathrm{i}} \Delta \mathrm{dsav}_{\mathrm{t}-1}+\eta \mathrm{ECT}_{\mathrm{t}-1}
\end{aligned}
$$

Table 4.6 presents the empirical estimate of the ARDL model. First, it presents the long-run estimates and next reports the short-run and error correction estimates of the model. The long-run coefficient results confirm statistically significant effects of borrowing and economic growth in Nepal. Further, there are significant 
positive effects of trade openness and domestic savings on economic growth. However, the positive and significant coefficient of population (1.48) is against the Solow prediction. Moreover, the estimated coefficient of the quadratic form in the growth equation has been found to be negative and significant, implying that result can be plotted on a public debt/ growth scatter plot to determine the optimal public debt. The trade openness result supports the view that free trade stimulates growth (Felipe et al. 2010).

\section{Table 4.6: Long-run and short-run estimation results}

\begin{tabular}{|c|c|c|c|}
\hline Variable & Co-efficient & Variable & Co-efficient \\
\hline \multicolumn{2}{|l|}{ Panel (A) } & \multicolumn{2}{|l|}{ Panel (B) } \\
\hline \multicolumn{2}{|c|}{ Long-run estimates } & \multicolumn{2}{|c|}{ Short-run estimates } \\
\hline \multicolumn{2}{|c|}{ ARDL lag selection $(1,2,1,0,0,0,0)$} & \multicolumn{2}{|c|}{ ARDL lag selection $(1,2,1,0,0,0,0)$} \\
\hline PDR & $\begin{array}{l}0.26 * * * \\
(2.73)\end{array}$ & $\mathrm{D}(\mathrm{PDR})$ & \begin{tabular}{|l|}
-0.23 \\
$(-0.63)$
\end{tabular} \\
\hline PDR_2 & $\begin{array}{l}-0.004 * * * \\
(-3.05)\end{array}$ & $\mathrm{D}(\operatorname{PDR}(-1))$ & $\begin{array}{l}0.22 * * \\
(2.33)\end{array}$ \\
\hline TROPEN & $\begin{array}{l}0.28^{*} \\
(2.02)\end{array}$ & $\mathrm{D}\left(\mathrm{PDR} \_2\right)$ & $\begin{array}{l}-0.001 \\
(0.48)\end{array}$ \\
\hline GFCI & $\begin{array}{l}-0.26^{*} \\
(-1.72)\end{array}$ & D(TROPEN) & $\begin{array}{l}0.39 * * \\
(2.10)\end{array}$ \\
\hline $\mathrm{POP}^{5}$ & $\begin{array}{l}1.48^{* * *} \\
(2.21)\end{array}$ & $\mathrm{D}(\mathrm{GFCI})$ & $\begin{array}{l}-0.36^{*} \\
(-1.79)\end{array}$ \\
\hline DSAV & $\begin{array}{l}0.21 * * \\
(2.01)\end{array}$ & $\mathrm{D}(\mathrm{POP})$ & $\begin{array}{l}2.03 * * \\
(2.25)\end{array}$ \\
\hline \multirow[t]{2}{*}{$\mathrm{C}$} & $\begin{array}{l}-6.35 * * * \\
(-2.38)\end{array}$ & $\mathrm{D}(\mathrm{DSAV})$ & $\begin{array}{l}0.29 * * \\
(1.96) \\
\end{array}$ \\
\hline & & CointEq(-1) & $\begin{array}{l}-1.37 * * * \\
(-9.81)\end{array}$ \\
\hline D-W stat & 2.19 & & \\
\hline F-stat & $13.45 * * *$ & $\mathrm{R} 2$ & 0.79 \\
\hline
\end{tabular}

Note: *Significant at 10 per cent level, **at 5 per cent level and $* * *$ at 1 per cent level

5 The coefficient of change in population is positive and significant is also confirmed by Paniza and Presbitero (2014) and Ashfaq \& Padda (2020) where the studies found the coefficient 3.6 for OECD countries and 5.36 for Pakistan respectively. 
After estimating the long-run coefficients, the final step in the ARDL approach is the analysis of error correction and estimation of short-run coefficients. According to the relevant theory, if there is cointegration among the variables, in the long run, the errors are corrected in the short run, and error correction will also happen in the short run. If there appears any disequilibrium that may come from any shock, the ECM can correct it which implies the speed of adjustment. Table 4.6 further reveals that the error correction term (ECT) coefficient is negative and significant. Some studies also suggest that ECT coefficient value should be between zero to one, but in negative. In this study, the coefficient has been estimated -1.37 , a higher value than one in absolute term. A similar finding has been reported by Ashfaq and Padda (2019) in the public debt-growth relationship of Pakistan where the ECT coefficient is -2.48 . However, Atique and Malik (2012) also suggested that ECT value can be more than minus one in absolute terms.

Short-term coefficients also confirmed that public borrowing has a quadratic relationship with Nepal's economic growth. In the short run, an increase in the public debt will boost economic growth up and after some period an additional increase in debt will decline the growth. In the short run, population growth, trade openness, domestic savings, and gross fixed capital formation have a direct and significant impact on the economic growth of Nepal.

In order to ensure the robustness of the model, it could be useful to evaluate the sensitivity of the parameters to make sure that there is no serial correlation among the regressors, the model is properly specified, the residuals are normally distributed and that it is free from heteroscedasticity. The diagnostic test results of the model are presented in Table 4.7. The observed coefficient reveals that there is no serial correlation among the residuals if the F-statistic of the Breusch-Godfrey Serial Correlation LM Test has been taken into consideration. However, observed Chi-square value implies the serial correlation in the residual of the model. The test for heteroscedasticity confirms that residuals are homoscedastic and the Jarque-Bera value confirms the normal distribution of the residuals of the model. 
Table 4.7: Results of diagnostic test

\begin{tabular}{|l|l|l|l|}
\hline Diagnostic test & Ch-square & F-Statistic & Jarque-Bera \\
\hline Breusch-Godfrey & 7.21 & 3.00 & - \\
Correlation LM Test & $(0.02)$ & $(0.06)$ & \\
\hline Heteroskedasticity: & 14.10 & 1.56 & - \\
Breuch-Pagan-Godfrey test & $(0.16)$ & $(0.16)$ & \\
\hline Normality test & - & - & 1.09 \\
& & & $(0.57)$ \\
\hline
\end{tabular}

To test the null hypothesis of model stability, this study has applied the cumulative sum of the recursive residuals (CUSUM) test. CUSUM statistics and band represents the bound of the critical region significant for the test at a five per cent significance level. If the cumulative sum goes outside the area between the critical lines, it indicates parameter instability. Figure 4.4 plot the results of CUSUM tests. The results show that the plot of the CUSUM statistic stays within the critical bounds of the five per cent confidence interval, implying not a rejection of the null hypothesis of stability. The test further supports the absence of any instability of the regression coefficients.

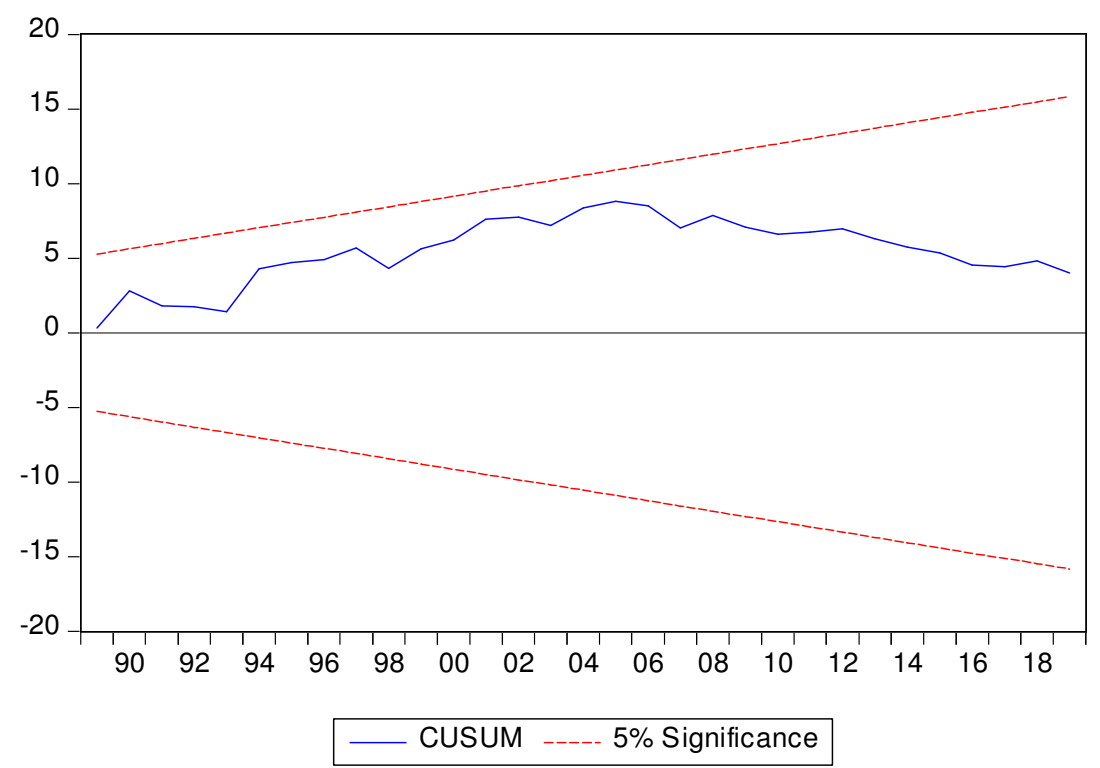

Figure 4.4: CUSUM test

Although it is common practice to regress economic growth on the array of potential determinants, the usefulness of this approach has increasingly been questioned by a number of studies (Sala-i-Martin, 1997, Levine \& Renelt, 1992). 
Bosworth and Collins (2003) suggest the need to focus only on a core set of variables of interest and evaluate the importance of other variables conditional on the inclusion of the core set (Kumar \& Woo, 2010). As such the analysis of growth maximizing public debt threshold in this paper focused mainly on the link between debt and growth.

\subsection{Debt-growth relationship and optimal debt to GDP ratio}

The ARDL model supports to estimate a quadratic form of model to find out the optimum level of government borrowing for economic growth of Nepal. The coefficients of public debt and public debt 2 from Table 4.6 show that both the variables are significant in the long-run. Moreover, the debt coefficients confirm that the debt growth relationship is a non-linear concave relationship, as the coefficient of debt is positive and the sign of debt 2 is negative in all specifications of ARDL model. The debt point estimates confirm the concave debt-growth relationship. Such a finding implies that low debt to GDP ratios contribute to economic growth, up to the point that the debt ratios pass a certain threshold for which the adverse effects of public debt 2 are larger than the initial positive effects of debt.

This paper focuses mainly on the relationship between public debt and economic growth, a bivariate model has been estimated to examine the optimum growth maximizing public debt threshold. The plot assists in determining the existence of a Laffer curve type relationship. The plot from the econometric results of the estimated quadratic bivariate equation 4.4 is shown in Figure 4.5.

$$
\mathrm{RGDP}=0.26 \mathrm{PDR}-0.004 \mathrm{PDR} 2
$$

The curve in Figure 4.5 depicts a concave or inverted U-shaped relationship between economic growth rates and public debt to GDP ratio. The results suggest that Nepal achieved higher growth rates when the public debt to GDP ratio is around 30 to 35 per cent. The point estimate of the public debt threshold for Nepal is 33 per cent. This result also confirms the debt overhang hypothesis found with respect to the link between external debt and growth in low-income countries (Cordellaet al., 2010) 




Figure 4.5: Optimal level of public debt for economic growth of Nepal

The debt threshold estimated for Nepal is too low compared to the conventional benchmark of 90 per cent as reported by Reinhart and Rogoff (2010) for highincome countries. Butkus and Seputine (2018) found debt turning points vary from 46 per cent to 229 per cent and from eight per cent to 145 per cent of GDP in countries with respectively high and low government effectiveness. The study further identified that countries with better quality of governance and lower levels of trade deficit have a higher debt threshold level. The estimated public debt ratio threshold for Nepal is also lower than the 38 per cent public debt to GDP ratio calibrated by the International Monetary Fund (IMF) and World Bank (WB) for low-income countries rated weak in terms of country performance and institutional assessment (CPIA).

\section{DISCUSSION AND CONCLUSION}

There is a wide discussion of the question, whether public debt is a means or burden of economic growth, in the scientific literature. The theory provides arguments on how government borrowings and increasing debt can stimulate, impede, or make no influence in economic growth. There is quite a lot of empirical research devoted to the analysis of the impact the public debt makes on economic growth, despite this, results are ambiguous. The growing number of recent studies in this field confirmed the non-linear inverted U-shaped public-debt growth nexus above which relationship turns from positive to negative, however, the estimated public debt-growth threshold level varies sharply across the studies. This raises the need to analyze key factors, that might determine the debt threshold. This study has empirically investigated the debt-to-GDP, and other economic determinants (population, investments, trade openness, and domestic savings) on the economic growth of Nepal. The results indicate that all variables, 
in the long run, have a positive contribution to economic growth except for gross fixed capital investment.

The main empirical results provide evidence for the existence of a non-linear relationship between economic growth and public debt. Our findings are in line with Woo and Kumar (2015), Ahlborn and Schweickert (2018), Ashfaq and Padda (2019), and Mupunga and Roux (2015), which suggest that the debt-growth relationship has an inverted U-shaped form. This implies the debt accumulation beyond the threshold ratio of 33 per cent would impact negatively on the economic growth of Nepal. The implication of the results of this paper is to provide a quantitative estimate of the growth impact of high indebtedness. This further helps in formulating the debt management strategy in line with the fiscal consolidation and growth acceleration agenda of the country.

Though the Government of Nepal has restrained its debt level below 30 per cent in recent pasts which was a part of fiscal discipline and a part of reform measure in budget formulation and implementation, the signals are not encouraging later years from the perspective of public debt -to- GDP ratio. A high level of public debt, particularly from external borrowing, requires safety measures against potential macroeconomic shocks.

This paper is confined to identify the optimum level of public debt beyond which the debt adversely affects economic growth in the context of Nepal. However, the analysis can be extended further by utilizing other approaches and control variables. As suggested by Bannister and Barrot (2011), other approaches of interest include examining the efficacy of fiscal policy at alternative debt levels. An instrumental variable approach might also be a possible technique to analyse the optimum debt thresholds in the context of Nepal.

\section{REFERENCES}

Afonso, A., \& J. Jalles. 2013. Growth and productivity: The role of government debt. International Review of Economics and Finance, 25(c), 384-407.

Ahlborn, M., \& S. Rainer. 2018. Public debt and economic growth-Economic systems matter. International Economics \& Economic Policy, 15(2), 373-403.

Aiyagari, S., \& E. McGrattan. 1998. The optimum quantity of debt. Journal of Monetary Economics, 42(3), 447-469.

Akram, N. I., Khan, M., \& I. Husnain. 2011. Fiscal situation in Pakistan and its consequences for economic growth and poverty. American International Journal of Contemporary Research, 94-11. 
Arčabić, V., Tica, J., Lee, J., \& \& R. J. Sonora. 2018. Public debt and economic growth Conundrum: Nonlinearity and inter-temporal relationship. Studies in Nonlinear Dynamics and Econometrics, 22(1), 1-20.

Ashfaq, M., \& I. U. Padda. 2020. Estimating the optimal level of public debt for economic growth: An evidence from Pakistan. Quest Journal of Management and Social Sciences, 222-232. DOI: https://doi.org:10.3126/qjmss. v1i2.27441QJMSS.

Atique, R., \& K. Malik. 2012. Impact of domestic and external debt on the economic growth of Pakistan. World Applied Sciences Journal, 20(1), 120-129.

Bahal, G., Raissi, M., \& V. Tulin. 2018. Crowding-out or crowding-in? Public and private investment in India. World Development, 109, 323-333. https://doi.org/10.1016/j.worlddev.2018.05.004.

Bannister, G., \& L.-D. Barrot. 2011. A debt intolerance framework applied to Central America, Panama and the Dominican Republic. IMF Working Paper.

Barro, R. J. 1979. On the determination of the public debt. The Journal of Political Economy, 87(5), 940-971.

Bhattarai, K. 2013. Public debt in Nepal: an assessment. Economic Journal of Development Issues, 15 \& 16, 50-59.

Bilan, I. 2016. Overview of the main theories on the economic effects of public indebtedness. EIRP Proceedings, 11.

Blanchard, O. J. 1985. Debt, deficit, and finite horizons. Journal of Political Economy 93(2), 223- 247.

Bosworth, B., \& S. Collins. 2003. The empirics of growth: An update. Brookings Papers on Economic Activity, 2.

Brida, J., Gómez, D., \& M. Seijas. 2017. Debt and growth: A non-parametric approach. Physica A, http://dx.doi.org/10.1016/j.physa.2017.05.060, 883-894.

Burhanudin, M. D., Muda, R., Nathan, S. B., \& R. Arshad. 2017. Real effects of government debt on sustainable economic growth in Malaysia. Journal of International Studies, 10(3), 161-172.

Butkus, M., \& J. Seputiene. 2018. Growth effect of public debt: The role of government effectiveness and trade balance. Economies, 6(4), 1-26. https://doi.org/10.3390/economies6040062.

Cecchetti, S., Mohanty, M., \& F. Zampolli. 2011. The real effects of debt. BIS Working Paper . Retrieved from BIS Working Paper: https://papers.ssrn.com/ sol3/papers.cfm?abstract_id=1946170

Checherita, C., \& P. Rother. 2010. The impact of high and growing government debt on economic growth - an empirical investigation for the euro area. ECB Working Paper No. 1237. 
Checherita-Westphal, C., \& P. Rother. 2012. The impact of high government debt on economic growth and its channels: An empirical investigation for the euro area. European Economic Review, 56(7), 1392-1405.

Chen, C., Yao, S., Hu, P., \& Y. Lin. 2017. Optimal government investment and public debt in an economic growth. China Economic Review, 45(c), 257-278.

Chudik, A., Mohaddes, K., Hashem Pesaran, M., \& M. Raissi. 2017. Is there a debtthreshold effect on output growth? Review of Economics and Statistics, 99(1), $135-150$.

Cordella, T., Ricci, L. A., \& M. Ruiz-Arranz. 2010. Debt overhang or debt irrelevance? IMF Staff Papers 57: 1-24.

Da Costa, E. E. 2010. Public debt sustainability. In A. C. Silva, L. O. de Carvalho, and O. L. de Medeiros, Public debt: the Brazilian experience (pp. 73-89). Brasilia: National Treasury.

De Vita, G., Trachanas, E., \& Y. Luo. 2018. Revisiting the Bi-directional causality between debt and growth: Evidence from linear and nonlinear tests. Journal of International Money and Finance, 83(c), 55-74.

Diamond, P. A. 1965. National debt in a neoclassical growth model. The American Economic Review, 55(5), 1126- 1150.

Elmendorf, D. W., \& N. G. Mankiw. 1998. Government debt. NBER Working Paper, 6470 .

Esteve, V., \& C. Tamarit. 2018. Public debt and economic growth in Spain, 18512013. Cliometrica, 12(2), 219-249.

Ewaida, H. Y. 2017. The impact of sovereign debt on growth: An empirical study on GIIPS versus JUUSD countries. European Research Studies Journal, 20(2), 607633.

Felipe, J., McCombie, J., \& K. Naqvi. 2010. Is Pakistan's growth rate balance of payments constrained? Policies and implications for development and growth. Oxford Development Studies, 38(4), 477-496.

Gómez-Puig, M., \& S. Sosvilla-Rivero. 2017. Heterogeneity in the debt-growth nexus: Evidence from EMU countries. International Review of Economics and Finance, 51(c), 470-486.

Jernej, M., Aleksander, A., \& V. Miroslav. 2015. Revisiting the role of public debt in economic growth: The case of OECD. Inzinerine Ekonomika-Engineering Economics, 26(1), 61-66.

Karadam, D. Y. 2018. An investigation of nonlinear effects of debt on growth. Journal of Economic Asymmetries, 18(c), 1-13.

Kim, E., Ha, Y., \& S. Kim. 2017. Public debt, corruption and sustainable economic growth. Sustainability, 9(3), 433. https://doi.org/10.3390/su9030433. 
Krugman, P. 1988) Financing vs. forgiving a debt overhang. Journal of Development Economics, 29(3), 253-268.

Kumar, M., \& J. Woo. 2010. Public debt and growth. IMF Working Paper 10/174.

Landais, B. 1998. Lecons de politique budgetaire/ Budgetary policy lessons. Bruxelles: De Boeck Universite.

Lee, S., Park, H., Seo, M. H., \& Y. Shin. 2017. Testing for a debt-threshold effect on output growth. Fiscal Studies, 38(4), 701-717.

Levine, R., \& D. Renelt. 1992. A sensitivity analysis of cross-country growth regressions. American Economic Review, 82(4), 942-963.

Modigliani, F. 1961. Long-run implications of alternative fiscal policies and the burden of the national debt. Economic Journal, 71(284), 730-755.

Mupunga, N., \& P. Roux. 2015. Estimating the optimal growth-maximising public debt threshold for Zimbabwe. Southern African Business Review, 19(3), 102128.

Panizza, U., \& A. F. Presbitero. 2014. Public debt and economic growth: Is there a causal effect? Journal of Macroeconomics, 41(c), 21-41.

Pegkas, P. 2018. The effect of government debt and other determinants on economic growth: The Greek experience. Economies, 6(1), 1-19.

Pesaran, H. M., Shin, Y., \& R. J. Smith. 2001. Bounds test approaches to the analysis of level lelationships. Journal of Applied Econometricsy, 16(3), 289-326.

Ra, S., Rhee, C., \& J. Hahm. 2005. Debt management analysis of Nepal's public debt. ERD Technical Note No. 15, ADB.

Rahman, N. H., Ismail, S., \& A. R. Ridzuan. 2019. How does public debt affect economic growth? A systematic review. Cogent Business \& Management, 6(1), $1-16$.

Reinhart, C. M., \& K. S. Rogoff. 2009. The aftermath of financial crises. American Economic Review, 99(2), 466-472.

Reinhart, C. M., \& K. S. Rogoff. 2010. Growth in a Time of Debt. American Economic Review, 573-578.

Reinhart, C. M., Reinhart, V., \& K. Rogoff. 2015. Dealing with debt. Journal of International Economics, 96(1), 43-55 https://doi.org/10.1016/j.jinteco. 2014.11.001.

Ricardo, D. 2005. On the principles of political economy and taxation (1817). (in) The works and correspondence of David Ricardo (Ed. P. Straffa \& M.H. Dobb), Vol. 1, . Indianopolis: Liberty Fund.

Romer, D. 2012. Advanced macroeconomics, 4th Edition. New York: McGraw-Hill Irwin. 
Saint-Paul, G. 1992. Fiscal policy in an endogenous growth model. Quarterly Journal of Economics, 107(4), 1243-1259.

Sala-i-Martin, X. 1997. I just run two million regressions. American Economic Review, 87(2), 178-183.

Scherjon, M. 2017. The search for the optimal debt Level: determining the growthmaximising public debt-to-GDP ratio. Retrieved from file:///C:/Users/97798/Desktop/Public\%20Debt/Literature\%20Review/SCHERJ ON\%20The\%20search\%20for\%20optimal\%20debt\%20level.pdf

Shahor, T. 2018. The impact of public debt on economic growth in the Israeli economy. Israel Affairs, 24(2), 254-264.

Shkolnyk, I., \& V. Koilo. 2018. The relationship between external debt and economic growth: Empirical evidence from Ukraine and other emerging economies. Investment Management and Financial Innovations, 15(1), 387-400. doi:10.21511/imfi.15(1).2018.32.

Smith, A. 1904. An inquiry into the nature and causes of the wealth of nations (5th Edition). London: Methuen \& Co., Ltd.

Snieska, V., \& D. Burksaitiene. 2018. Panel data analysis of public and private debt and house price influence on GDP in the European Union countries. Engineering Economics, 29(2), 197-204.

Taher, H. 2017. The impact of government debt on economic growth: An empirical investigation of the Lebanese market. International Journal of Euro Mediterranean Studies, 10(1), 23-41.

United Nations. 2018. Sustainable development goals. Retrieved from https://www.un.org/sustainabledevelopment/

Wright, A., \& K. Grenade. 2014. Determining optimal public debt and debt-growth dynamics in Caribbean countries. Research in Applied Economics, 2(2), 87-115. 